\title{
Application of Reliability Centered Maintenance Concept to Petrochemical Industry
}

\author{
P. Umpawanwong \& P. Chutima \\ Faculty of Engineering/Industrial Engineering \\ Chulalongkorn University, Wangmai, Patumwan, Bangkok 10330, Thailand
}

ABSTRACT: Reliability Centered Maintenance (RCM) is a well-known method in several industries. RCM is a structure decision process to cost-effective determines and optimum maintenance requirements. This paper proposes the application of the RCM concept to a petrochemical case study. The results indicate that preventive maintenance plans and available time of maintenance staff are improved significantly.

KEYWORD: Reliability Centered Maintenance (RCM); Preventive Maintenance (PM)

\section{INTRODUCTION}

The production process in the case study is the oldest olefins production plant in Thailand which has 9,712 equipment in total classified into four groups, i.e. electrical, instrument, machinery and stationary, as shown in Table 1 and Figure 1.

Table 1: Number of equipment in production process

\begin{tabular}{|c|c|c|c|c|}
\hline \multirow{2}{*}{ Class } & \multicolumn{4}{|c|}{ Number of Equipment } \\
\cline { 2 - 5 } & Electrical & Instrument & Machinery & Stationary \\
\hline A & 109 & 522 & 48 & 373 \\
\hline B & 348 & 2,117 & 262 & 790 \\
\hline C & 580 & 3,290 & 288 & 985 \\
\hline Sum & 1,037 & 5,929 & 598 & 2,148 \\
\hline
\end{tabular}

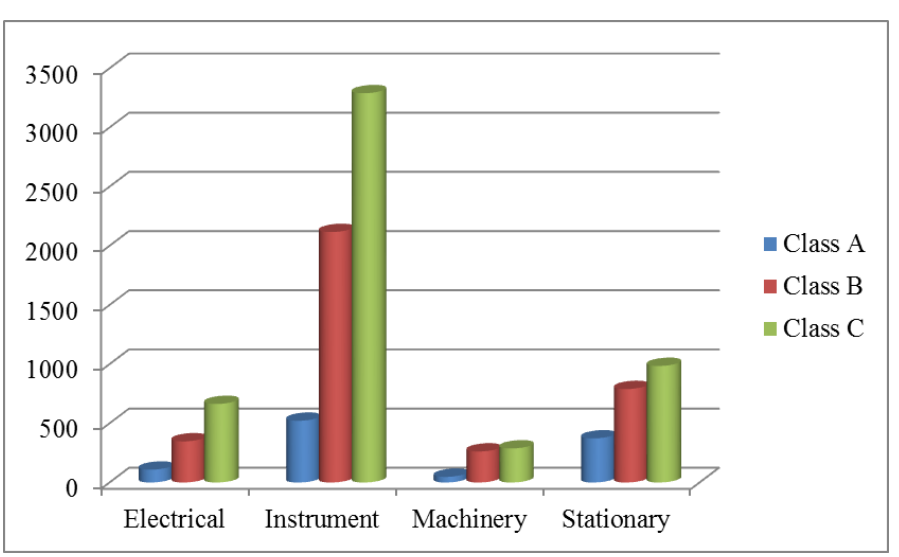

Figure 1: Proportion of equipment class in production process

In addition, if the equipment in class $\mathrm{A}$ fails, the production process will be totally shut down within 30 minutes. For class B's equipment, the impact to the production process is still high and the time to total shut down is more than 30 minutes. Whereas, there will be no effect to the process if the equipment in class $\mathrm{C}$ fails.

Table 2: Number of preventive maintenance plans in 2013

\begin{tabular}{|c|c|c|c|c|}
\hline \multirow{2}{*}{ Class } & \multicolumn{4}{|c|}{ Preventive Maintenance Plans } \\
\cline { 2 - 5 } & Electrical & Instrument & Machinery & Stationary \\
\hline A & 256 & 872 & 113 & 275 \\
\hline B & 692 & 1868 & 353 & 775 \\
\hline C & 1,324 & 471 & 173 & 460 \\
\hline Sum & 2,272 & 3,211 & 639 & 1,510 \\
\hline
\end{tabular}

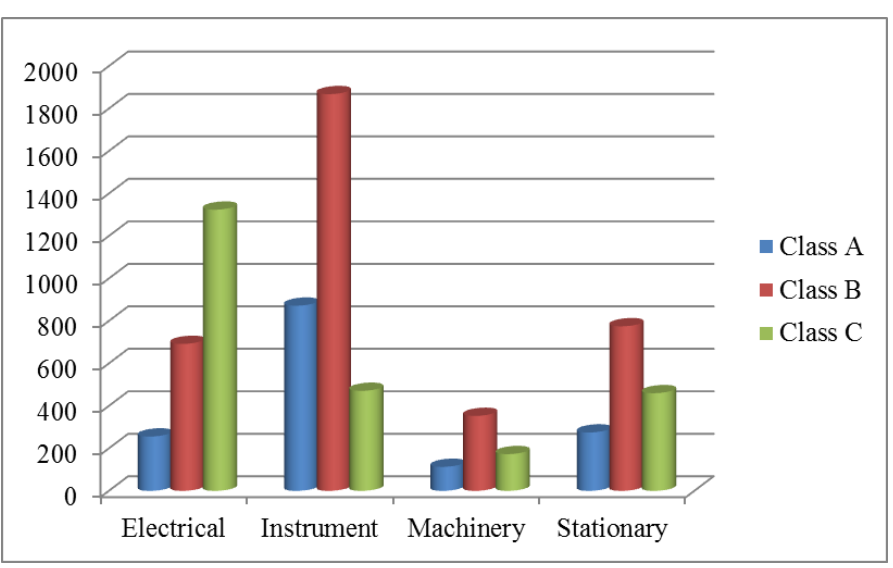

Figure 2: Proportion of preventive maintenance plans in 2013

From the 2013's maintenance report (Table 2 and Figure 2), the proportion of preventive maintenance plans in the electrical group was different from other groups observing from a high proportion of class $\mathrm{C}$ which should be normally low resulting in an excessive man-hour is used ineffectively in class $\mathrm{C}$. Therefore, the reliability centered maintenance (RCM) concept is applied to improve this problem. 


\section{LITERATURE SURVEY}

\subsection{Reliability Centered Maintenance (Moubray, 1997)}

Maintenance has been evolved through three generations. The first generation covered the period up to World War II. During the time, industry was not very highly mechanized. Hence, maintenance was simple whereby the machine was fixed only when it failed.

In the second generation (between 1950's and 1970 's), machines of all types were more complex. Then downtime came into focus and the concept of preventive maintenance became worldwide. In this period, a scheduled maintenance was planned in advance.

In the third generation (after 1970's), a big change in maintenance was noticed. The maintenance was expected not only to increase machine availability but also with minimum maintenance cost. As a result, the concept of RCM, which is a process to determine the maintenance requirements of physical equipment, was developed. Seven steps of the RCM process are shown in Figure 3.

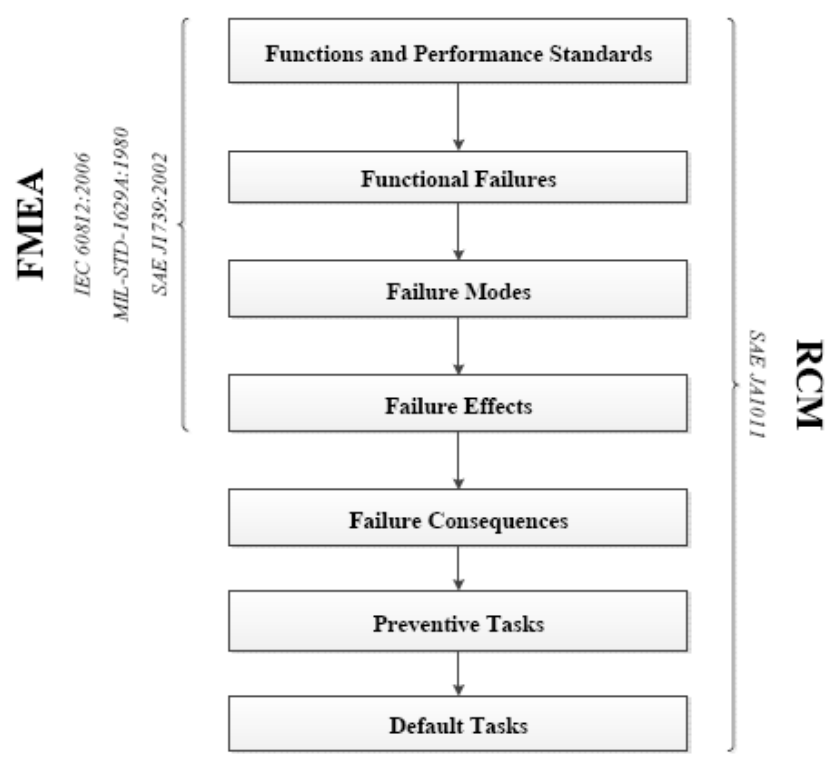

Figure 3: Seven steps of the RCM process

Step 1: Functions and performance standards: define the functions and performance standards of equipment.

Step 2: Functional failure: define the performance expectations of equipment.

Step 3: Failure modes: define the failure modes of equipment.

Step 4: Failure effects: define the failure effects of equipment at each failure mode.

Step 5: Failure consequences: define the failure consequences to the production process when the equipment cannot be in service at the expected level.

Step 6: Preventive tasks: choose the suitable maintenance strategy for all failure modes.
Step 7: Default tasks: update the new maintenance list and schedule in the computerized maintenance management system (CMMS)

\subsection{Literature Review}

Penrose (2005) proposed maintenance strategies which are suitable for motor management by using RCM techniques on electric motor. This paper describes about effective maintenance strategies such as condition-based monitoring (CBM) and assists maintenance staff for selecting the optimum in performing the right maintenance on the right equipment at the right time for the right reasons.

$\mathrm{Yu} \&$ Zhao (2005) proposed maintenance plan based on RCM, which considered the condition of electrical equipment and its importance in the power system network. The actual condition of electrical equipment can be identified based on various criteria. They suggested identifying the criticality equipment which must be maintained first.

Ozdemir \& Kuldasli (2010) proposed an RCM program for Turkish national power transmission system. This paper described steps of applying the RCM methodology and decision tree diagram for selecting right maintenance strategy to achieve the target to improve the reliability of the system by minimize the failure with applying appropriate maintenance procedure.

\section{RESEARCH METHODOGY}

The first step of RCM is data collection. Motor and switchgear which are the main equipment of class $\mathrm{C}$ are chosen in this study (Table 3). Normally the equipment with fully redundant has two units (one is on duty and the other is standby), whereas the equipment with not-fully redundant has only one.

Table 3: Motor and Switchgear data

\begin{tabular}{|l|c|c|c|c|}
\hline \multicolumn{1}{|c|}{ Type } & Class & $\begin{array}{c}\text { Fully } \\
\text { Redundant }\end{array}$ & $\begin{array}{c}\text { Not Fully } \\
\text { Redundant }\end{array}$ & Total \\
\hline Motor & $\mathrm{C}$ & 144 & 76 & 220 \\
\hline Switchgear & $\mathrm{C}$ & 250 & 81 & 331 \\
\hline
\end{tabular}

Appropriate maintenance strategies have been developed specifically for fully and not-fully redundant equipment. The functional failures, failure modes and failure consequences for each equipment group are shown in Tables 4 and 5 . 
Table 4: Motor RCM information form

\begin{tabular}{|c|c|c|c|}
\hline \multicolumn{4}{|c|}{ Equipment: Motor } \\
\hline $\begin{array}{l}\text { Function } \\
\text { (F) }\end{array}$ & $\begin{array}{c}\text { Functional } \\
\text { Failure (FF) }\end{array}$ & $\begin{array}{l}\text { Failure Mode } \\
\text { (FM) }\end{array}$ & $\begin{array}{c}\text { Failure } \\
\text { Consequence } \\
\text { (FC) }\end{array}$ \\
\hline \multirow{5}{*}{$\begin{array}{l}\text { Pump } \\
\text { Driver }\end{array}$} & \multirow{2}{*}{$\begin{array}{l}\text { Stator Winding } \\
\text { Insulation Failure }\end{array}$} & Over Current & \multirow{5}{*}{$\begin{array}{c}\text { Pump } \\
\text { Cannot Run }\end{array}$} \\
\hline & & Moisture & \\
\hline & \multirow[t]{2}{*}{ Bearing Failure } & $\begin{array}{l}\text { Lack of } \\
\text { Lubrication }\end{array}$ & \\
\hline & & Grease is Dirty & \\
\hline & $\begin{array}{l}\text { Cooling Fan } \\
\text { Failure }\end{array}$ & Ambient Temp & \\
\hline
\end{tabular}

Table 5: Switchgear RCM information form

Equipment: Switchgear

\begin{tabular}{|c|l|l|c|}
\hline $\begin{array}{c}\text { Function } \\
(\mathrm{F})\end{array}$ & \multicolumn{1}{|c|}{$\begin{array}{c}\text { Functional } \\
\text { Failure (FF) }\end{array}$} & $\begin{array}{c}\text { Failure Mode } \\
\text { (FM) }\end{array}$ & $\begin{array}{c}\text { Failure } \\
\text { Consequence } \\
\text { (FC) }\end{array}$ \\
\hline \multirow{2}{*}{$\begin{array}{c}\text { Power } \\
\text { Supply }\end{array}$} & Arc Flash & $\begin{array}{l}\text { High Contac } \\
\text { Resistance }\end{array}$ & \multirow{2}{*}{ outage } \\
\cline { 2 - 3 } & Nuisance Trip & $\begin{array}{l}\text { Protection Relay } \\
\text { Malfunction }\end{array}$ & \\
\hline
\end{tabular}

Decision tree is developed for selecting the right maintenance strategy to achieve the target, which can be explained as follows (Figure 4). Firstly, we have to know that whether the functional failure can be managed effectively or not. If it is not, the fixafter-fail strategy is used. If yes, we have to check whether the equipment is fully redundant or not. If the equipment is fully redundant, the run-to-fail strategy is used; otherwise, we have to further check whether the failure is age related or random. If it is an age-related failure, the time-based maintenance is used; otherwise, we have to use the condition based maintenance instead.

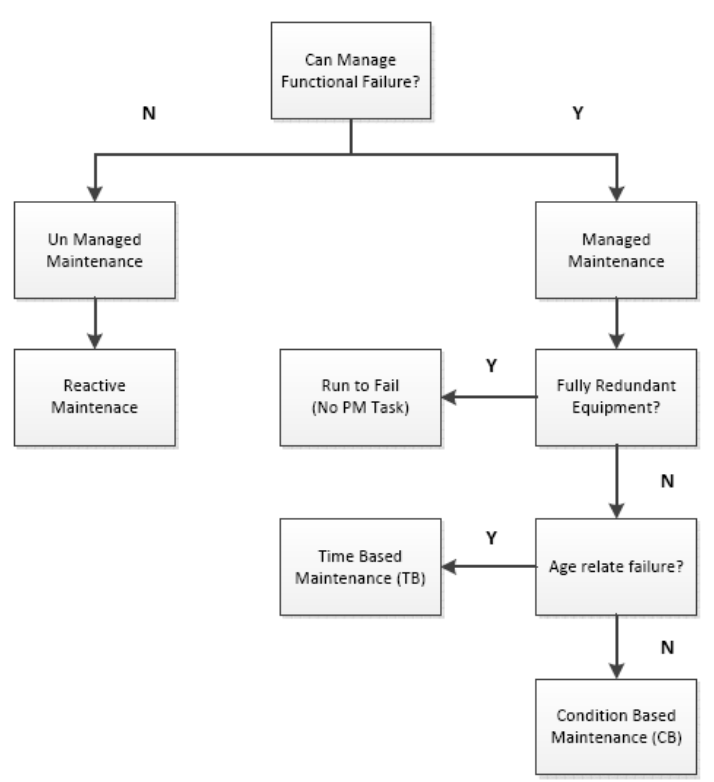

Figure 4: Decision tree for maintenance strategy
Following the guideline given in the decision tree, the maintenance strategies for motor and switchgear are shown in Tables 6 and 7, respectively.

Table 6: RCM Decision table for motor

Equipment: Motor

\begin{tabular}{|l|l|l|c|}
\hline \multicolumn{1}{|c|}{$\begin{array}{c}\text { Functional } \\
\text { Failure (FF) }\end{array}$} & \multicolumn{1}{|c|}{$\begin{array}{c}\text { Failure Mode } \\
\text { (FM) }\end{array}$} & Type of Failure & $\begin{array}{c}\text { PM } \\
\text { Task }\end{array}$ \\
\hline $\begin{array}{l}\text { Stator Winding } \\
\text { Insulation } \\
\text { Failure }\end{array}$ & Over Current & Random Failure & $\mathrm{CB}$ \\
\cline { 2 - 5 } Bearing Failure & $\begin{array}{l}\text { Moisture } \\
\text { Lubrication }\end{array}$ & Random Failure & $\mathrm{CB}$ \\
\cline { 2 - 5 } & Grease is Dirty & Random Failure & $\mathrm{CB}$ \\
\hline $\begin{array}{l}\text { Cooling Fan } \\
\text { Failure }\end{array}$ & Ambient Temp & Age Relate & $\mathrm{TB}$ \\
\hline
\end{tabular}

Table 7: RCM Decision table for switchgear

Equipment: Switchgear

\begin{tabular}{|c|l|c|c|}
\hline \multicolumn{1}{|c|}{$\begin{array}{c}\text { Functional } \\
\text { Failure (FF) }\end{array}$} & \multicolumn{1}{|c|}{$\begin{array}{c}\text { Failure Mode } \\
\text { (FM) }\end{array}$} & $\begin{array}{c}\text { Failure } \\
\text { Consequence } \\
\text { (FC) }\end{array}$ & $\begin{array}{c}\text { PM } \\
\text { Task }\end{array}$ \\
\hline Arc Flash & $\begin{array}{l}\text { High Contact } \\
\text { Resistance }\end{array}$ & Age Relate & TB \\
\hline Nuisance Trip & $\begin{array}{l}\text { Protection Relay } \\
\text { Malfunction }\end{array}$ & Random Failure & $\mathrm{CB}$ \\
\hline
\end{tabular}

\section{RESULTS}

The number of new total PM plans and the proportion of PM plans are improved significantly, as a result of improving PM plans by applying the RCM concept as shown in Table 8 and Figure 5.

Table 8: Comparison between existing and new PM plans

\begin{tabular}{|c|c|c|}
\hline \multirow{2}{*}{ Class } & \multicolumn{2}{|c|}{ Electrical PM Plans } \\
\cline { 2 - 3 } & Before Improve & After Improve \\
\hline A & 256 & 256 \\
\hline B & 692 & 692 \\
\hline C & 1,324 & 443 \\
\hline
\end{tabular}

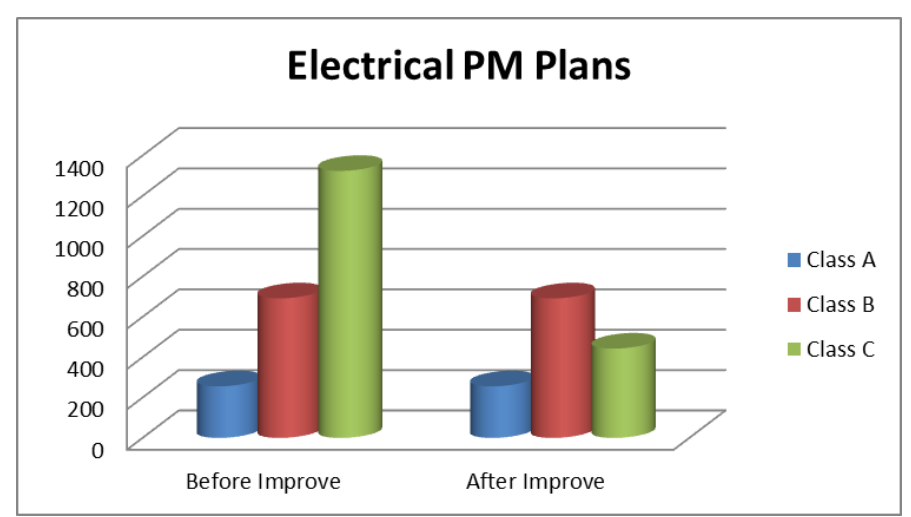

Figure 5: Comparison between existing and new PM plans 
In addition, it is noticed that the maintenance cost is reduced and the available man-hour of maintenance staff is increased substantially as shown in Table 9.

Table 9: Maintenance cost saving

\begin{tabular}{|c|c|c|}
\hline $\begin{array}{c}\text { Electrical } \\
\text { PM Plans }\end{array}$ & $\begin{array}{c}\text { Man Hour/Year } \\
\text { (Hrs.) }\end{array}$ & $\begin{array}{c}\text { Maintenance Cost/Year } \\
\text { (USD) }\end{array}$ \\
\hline Before Improve & 7,944 & 47,664 \\
\hline After Improve & 2,658 & 15,948 \\
\hline Total Saving & 5,286 & 31,716 \\
\hline
\end{tabular}

\section{CONCLUSION}

Normally the concept of RCM is applied for class A's equipment to improve the mean time between failure. However, this study shows that this concept is also applicable to class C's as well. The goal is to reduce maintenance cost and increase the available man-hour of maintenance staff. The results from this study indicate that the concept of RCM can also apply to class's $\mathrm{C}$ and it could result in significant improvement in terms of cost and man-power requirement.

\section{REFERENCES}

[1] Moubray, J. 1997. Reliability Centered Maintenance. Oxford: Butterworth-Heinemann Elsevier.

[2] Narayan, V. 2003. Effective Maintenance Management Risk and Reliability Strategies for Optimizing Performance.

[3] Penrose, H.W. 2005. RCM-Based Motor Management.

[4] Yu, J. \& Zhao, H. 2005. Maintenance plan based on RCM. IEEE/PES Transmission and Distribution Conference \& Exhibition: Asia and Pacific Dalian, China.

[5] Ozdemir, A. \& Kuldasli E.D. 2010. RCM Application for Turkish National Power Transmission System.

[6] Itakura, S. Niioka, S. Magori, H. Iba, K. Chen, L. Shirai, G. \& Yokoyama, R. 2006. A Strategic Reliability Centered Maintenance for Electrical Equipment in a Chemical Plant. 9th International Conference on Probabilistic Methods Applied to Power Systems KTH, Stockholm, Sweden - June 11-15, 2006.

[7] Chen, Y. \& Zhang, T. 2012. Application \& Development of Reliability-Centered Maintenance (RCM) in China's Nuclear Energy Field.

[8] Bertling, L. 2005. On evaluation of RCM for maintenance management of electrical power systems. Proceedings of Power Engineering Society General Meeting, pp. 26382640. U.S.A

[9] Johnston, D.C. 2002. Measuring RCM Implementation. Proceedings of Annual Reliability and Maintainability Symposium. United Space Alliance, Cape Canaveral. U.S.A 